\title{
Investigation of Solar Powered Drying System Potential in Niğde Province ${ }^{\#}$
}

\author{
Yaşar Serhat Saygılı 1,a,", Ali Kaan Yetik ${ }^{1, b}$, Furkan Baş ${ }^{1, \mathrm{c}}$, Burak Şen ${ }^{1, d}$ \\ ${ }^{1}$ Department of Biosystems Engineering, TBTF, Niğde Ömer Halisdemir University, 51240 Niğde, Turkey \\ *Corresponding author

\begin{tabular}{|c|c|}
\hline R T I C L E I N & $\mathrm{T}$ \\
\hline $\begin{array}{l}{ }^{\#} \text { This study was presented as an online } \\
\text { presentation at the } 2 \text { nd International } \\
\text { Journal of Agriculture - Food Science } \\
\text { and Technology (TURJAF 2021) } \\
\text { Gazimağusa/Cyprus } \\
\text { Review Article }\end{array}$ & 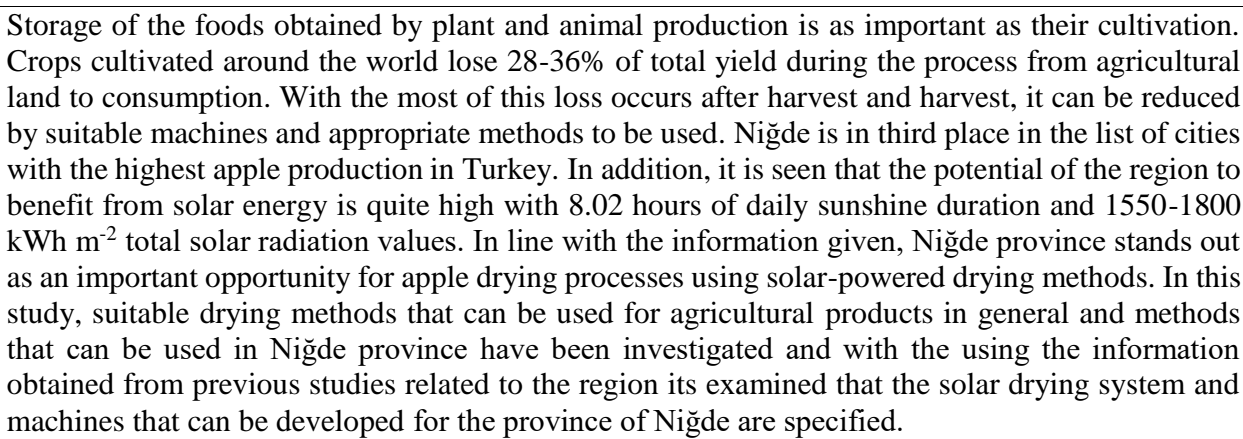 \\
\hline
\end{tabular} \\ Drying machines \\ Apple drying \\ Solar energy \\ Agricultural production \\ Food storage \\ serhatsaygili@ohu.edu.tr (D) https://orcid.org/0000-0001-6974-3820 \\ c@furkanbas@ohu.edu.tr

\section{Introduction}

Protection of agricultural products, which have an important place in the nutrition of people; it is as important as its cultivation, and it is known that it suffers some losses from its production to its consumption. For example, it is estimated that the losses in cereals from harvest to consumption account for about $18 \%$ of annual production, and the losses in fruits and vegetables reach $35-40 \%$ of annual production (Kibar ve Öztürk, 2010; Oral, 2015). In addition to the damage caused by the loss of nutrients for humans, the economic losses suffered by the producer are also undeniable. There are many methods and applications to increase the economic life of agricultural products that can be used during their journeys from production to consumption, as well as to ensure the preservation of nutritional values. These methods can be classified as pasteurization, cooling, atmospheric control application, chemical applications, beta and gamma rays' application and drying. The most widely used and most economical method is drying. Drying is defined as the process of removing moisture and/or volatile substances by applying thermal methods to solid substances and is increasingly important (Güngör, 2013).
One of the methods that allows harvested agricultural products to be stored for a long time is to prevent the growth and proliferation of microorganisms by reducing the amount of water contained in the product. Logistics and storage costs are also reduced as the volume and weight of dried agricultural products are reduced in the drying process. The drying process is one of the oldest methods used to protect food. Food products, especially fruits and vegetables, need hot air in the temperature range of 45$60^{\circ} \mathrm{C}$ for safe drying. Drying process is applied in many regions of the world and the technologies used in practice and usage are developing. While the principles of sun drying are remained the same, drying process has turned into both short and more efficient drying methods. Although solar drying has cost advantages, it causes huge losses in terms of quality. Drying under controlled temperature and humidity conditions helps agricultural food products dry up to a safe moisture content at a reasonable rate and ensure a superior stay of the product (Sharma et al., 1995). 
Controlled drying is mostly applied in industrial drying processes. Machineries and equipment's used for industrial drying applications consume a high level of energy and fossil fuels are often used to supply this energy demand. Intensive use of fossil fuels to meet energy demand leads to rapid depletion of resources and environmental pollution. Greenhouse gases released into the atmosphere are the leading environmental pollution caused by fossil fuels.

The use of renewable energy sources to provide the necessary energy for the machinery and equipment used in drying is of great importance for sustainable agriculture and environmental protection and provides an alternative to the problems caused by fossil fuels. Solar energy, which is one of the leading renewable energy sources, can be used both passively and actively in drying systems. By developing this application in our country and using it more effectively, important contributions can be made in the field of sustainable agriculture. In addition, by increasing the use of renewable energy sources in agriculture, significant contributions can be made to renewable energy targets of Turkey. A map of solar energy business potential of Turkey is given in Figure 1 (TCETKB, 2021).

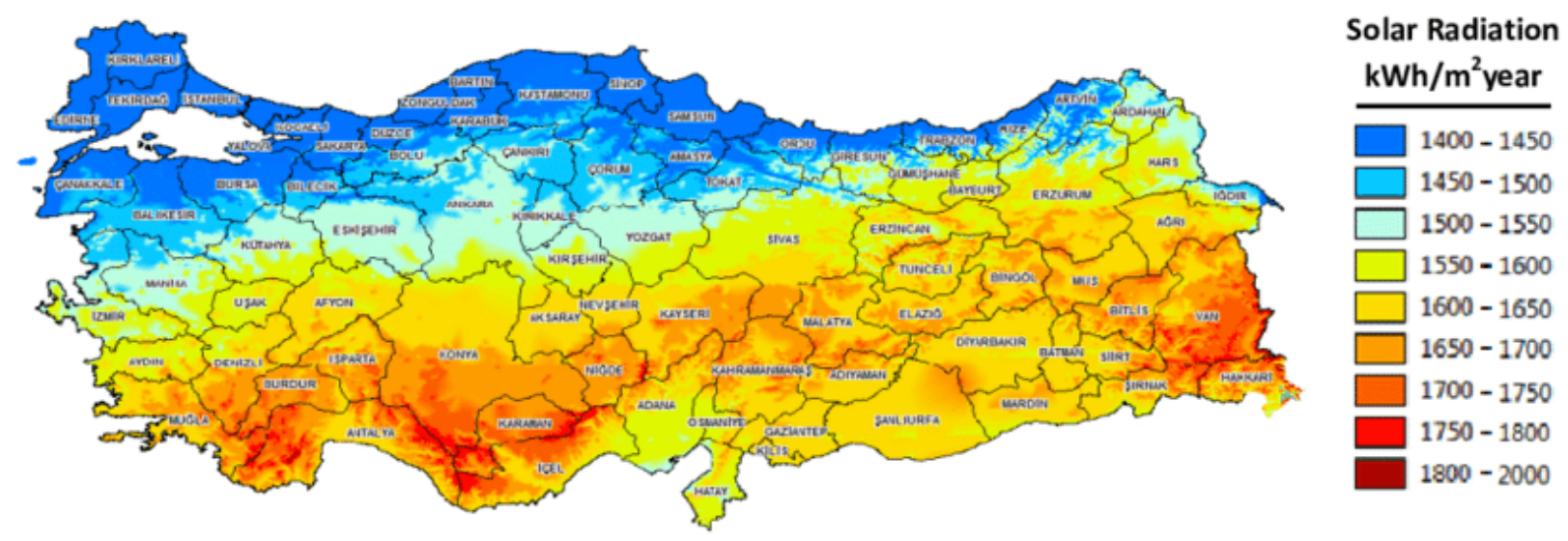

Figure 1. Turkey solar energy potential atlas (TCETKB, 2021).

When Figure 1 is examined, it is seen that Turkey has a wide solar energy potential extending from southwest to northeast. According to the data of the Ministry of Energy and Natural Resource, Turkey is on average; the total annual sunbathing time is 2741.07 hours year ${ }^{-1}$, the daily sunbathing time is 7.50 hours day ${ }^{-1}$, the radiation intensity is $1527.46 \mathrm{kWh} \mathrm{m}^{-2}$ year $^{-1}$, and the daily radiation intensity is $4.18 \mathrm{kWh} \mathrm{m}^{-2} \mathrm{day}^{-1}$ (TCETKB, 2021). When the data are evaluated, it is possible to say that Turkey's solar energy potential has reached high values.

Fossil fuel-powered dryers are often not suitable for small and family businesses due to large capital requirements and high operating costs. For these reasons, solar-powered dryers stand out both in terms of sustainability and maintenance and operating costs. Numerous experimental studies since the early 2000s have shown that agricultural products can be dried using solar energy. The performance of solar-powered dryers has been simulated, designed, tested and recommended by many researchers for drying purposes (Close, 1963; Whillier, 1964; Yadav and Tiwari, 1986; Banga et al, 1991; Yadav et al, 1995; Fatih, 1995; Aboul-Enein et al., 2000). Usage of solar energy for drying offers significant potential for drying agricultural crops such as cereals, fruits, vegetables and medicinal plants; it eliminates many of the challenges and consequences of solar drying and industrial drying, while preventing the use of large quantities of fossil fuels.

In tropical and semi-tropical regions, it is quite possible to use solar energy in thermal applications such as heating and drying. However, there are situations where this potential is high in regions with terrestrial climate characteristics, such as Niğde province in central Anatolia region. When the total solar radiation values of Niğde on the website of General Directorate of Energy Affairs are examined; $1.550-1.600 \mathrm{kWh} \mathrm{m}^{-2}$ year $^{-1}$ of the lowest values for the region. It was observed that the northern parts in the $600 \mathrm{kWh} \mathrm{m}^{-2}$ year $^{-1}$ and the highest values were in the eastern parts in the $1.750-1.800 \mathrm{kWh} \mathrm{m}^{-2}$ year $^{-1}$ (Figure 2a). When the sunbathing time data, another parameter considered when determining the potential for solar energy use, is examined, the average daily sunbathing time per year of Niğde Province is reported as 8.02 hours day $^{-1}$ (Figure 2b). This is above the Turkish average of 7.50 hours day ${ }^{-1}$ and makes it possible to evaluate the potential.

Turkey has achieved higher yields than world average yields in apple production between 1965 and 2017 years. While the total yield comparison shows an average difference of 4.7 tons of apple yield per hectare between the world and our country until the early 2000s, this value began to decrease with the world's adaptation to Industry 4.0 applications and decreased to 400 kilograms per hectare in 2015 (FAO, 2021). Niğde is a city that has strategic characteristic on apple production in Turkey. Although it ranks third in the Turkish rankings in terms of apple production, it is seen that the export rates and the quality parameters of the apples cultivated in Niğde are at the first place (TÜIK, 2021). In this respect, the contribution of the city is quite large to the economy of the 
country. For this economic contribution to increase, it is possible to create a different trading item and obtain higher profit values than the unit apple by subjecting the apples to drying. Niğde Omer Halisdemir University, which sells active dried apples in Niğde, has determined the sales price of apples produced in the Research and Application Center of the Faculty of Agricultural Sciences and Technologies as 10.00 Turkish Lira for 2020 in packages of 200 grams (NOHÜ, 2021a). The price set by the same institution for the sale of fresh apples was reported as $4.00 \mathrm{TL}$ for $1 \mathrm{~kg}$ of apples (NOHÜ, 2021b).

Apples are an important raw material for many food products (Ceylan et al., 2006; Kaya et al., 2007). In the literature, there are many experimental studies on determining the drying properties of various types of apples under different drying processes and conditions (Chiang and Petersen, 1987; Üretir et al., 1996; Lewicki and Jakubczky, 2004; Velić et al., 2004; Mayor et al., 2005; Srikiatden and Roberts, 2007; Saçılık and Eliçin, 2006). Drying temperature of the apple at the first stage ranged from $70-80^{\circ} \mathrm{C}$, while the second stage was set at $74^{\circ} \mathrm{C}$, while the average drying time was reported as 8 hours (Velić et al., 2004). When the studies are evaluated, it is seen that two different techniques stand out in the apple drying process. The first is to check the water content due to the decrease and increase in the mass values of apples, and the second is the methods by which measurements continue during drying processes. Before drying apples, their shells need to be peeled, decontaminated and sliced according to the thick values of 3-5.5 $\mathrm{mm}$ mentioned in the literature (Lewicki and Jakubczky, 2004). During the drying of the apple, the acids in it form a chemical reaction with oxygen and cause the appearance of brown profiles. This is a parameter in determining the quality of drying the apple, and the formation of brown profiles means that the quality is poor. It has been reported that the profiles mentioned in apples dried using drying ovens are less common in the studies (Mayor et al., 2005; Srikiatden and Roberts, 2007; Saçılık and Eliçin, 2006).
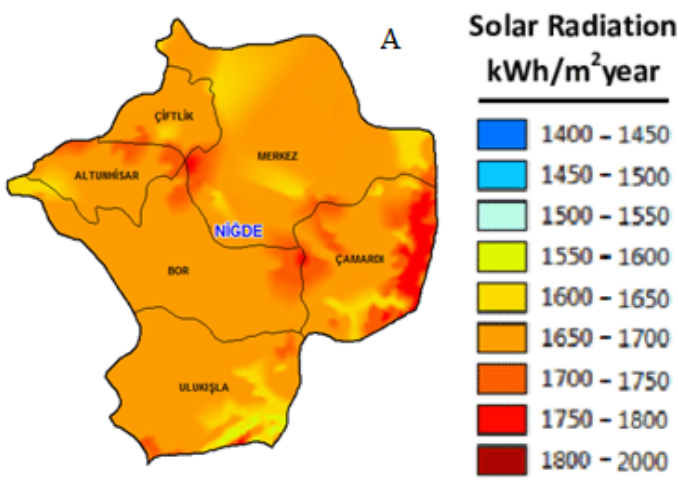

B

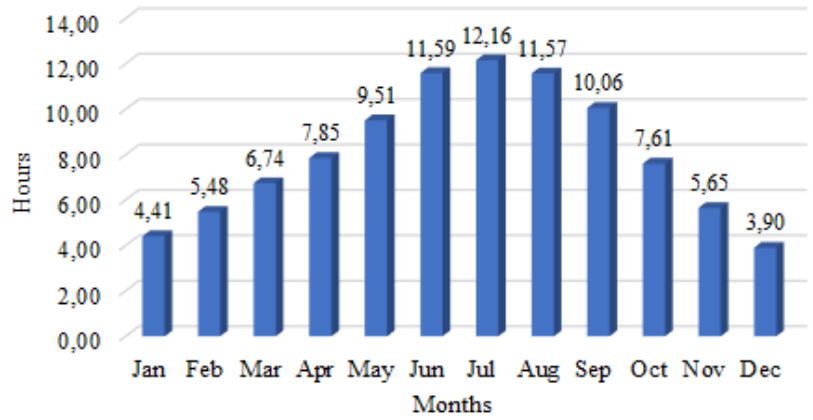

Figure 2. Total annual solar radiation in Niğde province and average daily sunbathing time for months (EİGM, 2021).

\section{Methods and Technologies Used in Vegetable and Fruit Drying}

Drying is one of the most popular and low cost food storage techniques used in every geography for centuries. Today, there are many methods applied for drying food, but there are three basic methods that are frequently preferred. These methods can be sorted as,

- Convection drying

- Induction drying

- $\quad$ Radiation drying (Ayensu, 1997; Baunga et al., 1991).

Convection drying is carried out by removing the water contained in the product using a hot gas (usually air). In the first stage, hot gas is passed through and around the substance to be dried and the water in the product evaporates during this transition. In the method of induction drying, the removal of water from the product is carried out by heat exchange between the product and the drying platform in which the product comes into contact. In radiation drying; because of the radiation and heat exchange between the product and the environment, the water in the product is removed. Convection drying method is more frequently used and there are many machines and equipment for this process.
Most of the existing drying methods are used for drying agricultural products. The oldest of these methods is sun drying. In most developing countries, the most used method to protect agricultural products such as cereals, fruits and vegetables is drying in the open sun. Although this method is simple; the exposedness of the products brings with it many negatives such as dust, rain, insects, birds and wind effect. In addition to the current disadvantages of outdoor drying, the deterioration of precipitation regimes with the effects of global climate change makes it increasingly difficult to use this form of drying of precipitation transitions that will occur in unexpected seasons. However, the sun drying method also requires a large drying area and long drying time. Drying in the sun under these conditions; leads to serious losses in the quantity and quality of the dried product (Pangavhane et al., 2002). Therefore, by using controlled methods of drying, yields can reduce losses and significantly increase the quality of the dried product compared to traditional drying methods such as drying in the sun or shade (Yaldız et al., 2001). 
Drying takes place in two stages. The first stage takes place on the surface of the drying material and the process of evaporation of water into the environment begins. The second stage begins with the decreasing drying rate and its condition is determined according to the characteristics of the dried material (Can, 2000).The success of the process depends on the selection of a suitable dryer in terms of both product quality and profitability of the enterprise. Due to the lack of a multipurpose dryer type suitable for drying each product, the correct choice of drying method and dryer as the first step is of great importance (Gürel et al., 2016). When choosing a dryer, the characteristic properties of dryers should be considered. A change in the operating conditions of the same dryer can affect the quality of the product. Therefore, it is also important to choose the right working conditions for optimum quality and the cost of getting thermal humidity in addition to the dryer type (Gürel et al., 2016; Güneş, 2009).

\section{Dryers}

For drying, it is necessary to expel the water from the product. Heat energy is usually used for the process of expelling water. The methods and conditions suitable for the product to be dried are selected and carried out.

The method widely used in drying processes in our country is convective drying with the help of airflow. Air flow dryers can be classified in several ways. According to the basic classification, the product can be divided into two as immobile and dried product moving. (Figure 3). These two groups are based on the temperature of the air to be used in the drying process.

- Powered by unheated air,

- Operated by air at low temperature (the temperature difference between drying air and ambiance air is between $6-10{ }^{\circ} \mathrm{C}$ ),

- which are air-powered at high temperatures.

- In the drying of fruits, vegetables and liquid products, cabin dryers, infinite tape dryers, fluid bed dryers and rotary type cylindrical dryers are usually used (Figure 4).

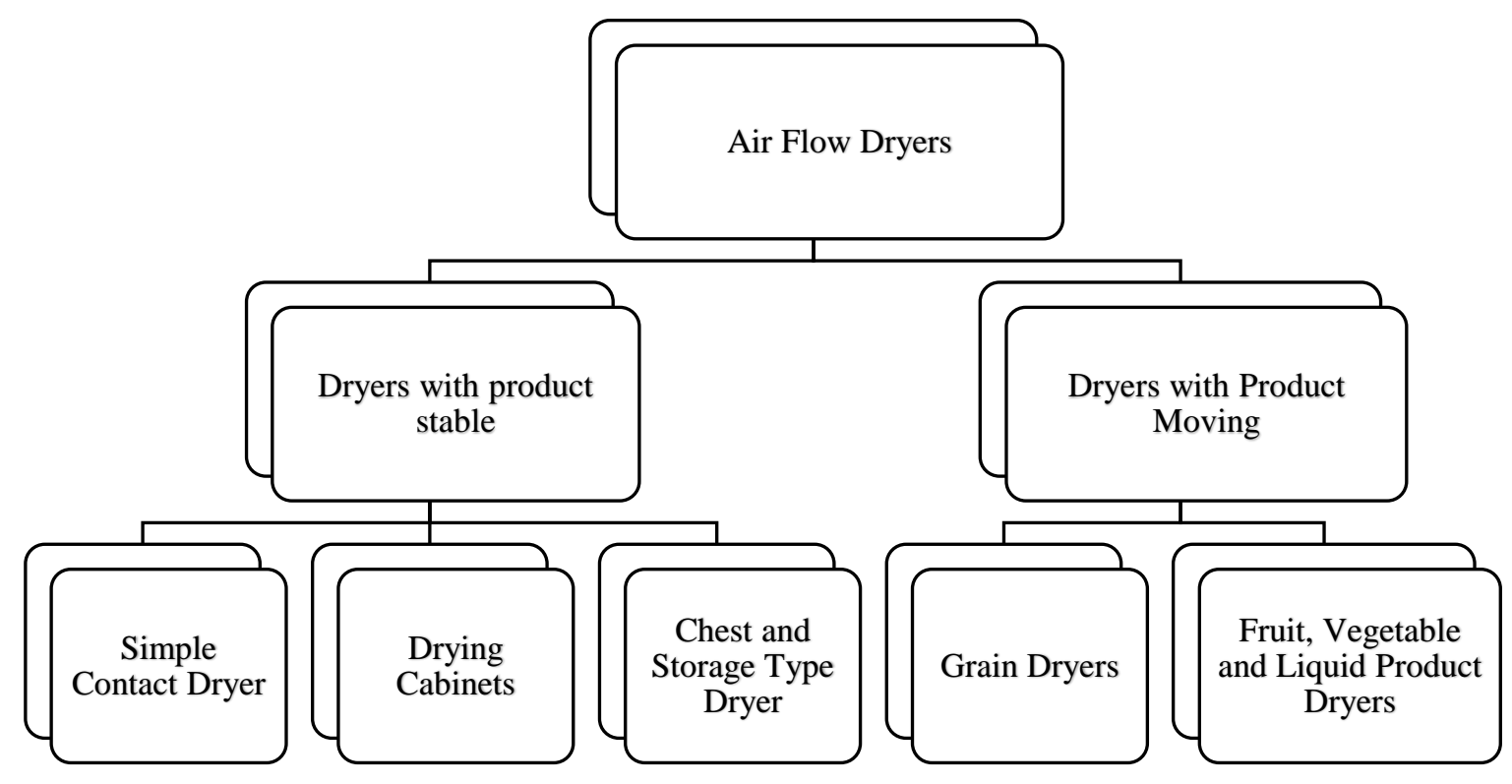

Figure 3. Air Flow Dryers (Yağcığlu, 1999; Özbalta ve Güngör, 2012; Çay et al., 2017)

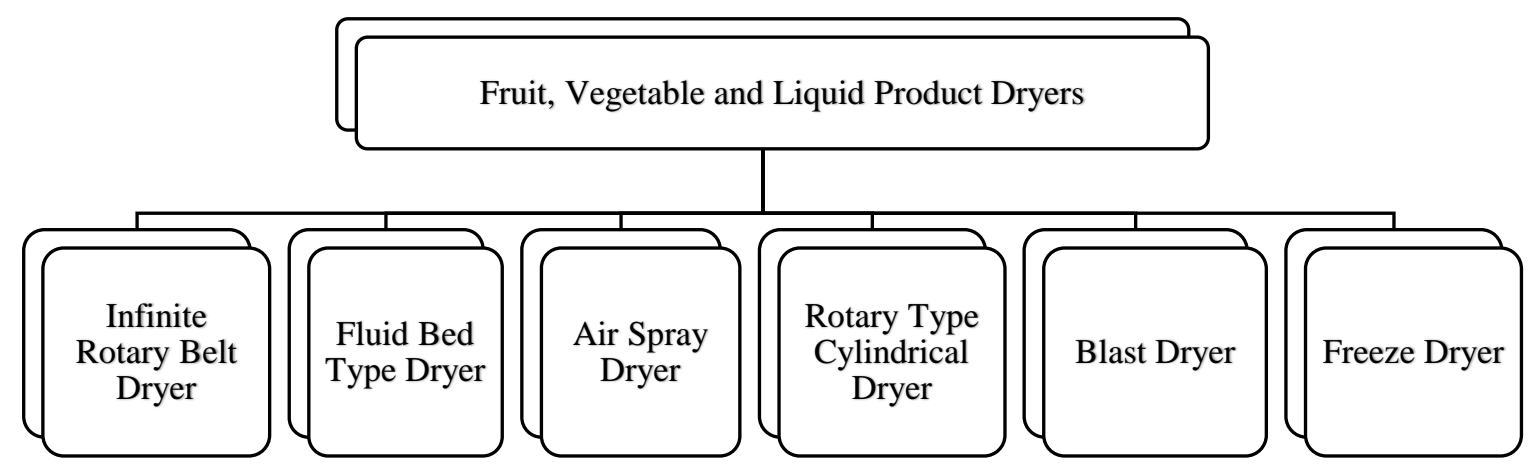

Figure 4. Fruit, Vegetable and Liquid Product Dryers (Yağc1oğlu, 1999) 


\section{Solar Collector Dryers}

The energy required in traditional drying technology is provided from various natural energy sources. High energy costs, expensive and external dependence of oil and derivative energy sources, in contrast, the fact that our country has a rich density of solar energy, and the drying time of agricultural products coincides with periods of high solar energy, increasingly necessitates the use of solar energy as a priority energy source in the drying process. Considering drying with solar-powered systems, the climatic characteristics of the area where the drying will be carried out should be carefully examined. Various climatic characteristics and solar radiation intensity are the most important factors affecting the design and performance of solar-powered dryers (Çakmak, 2007).

Solar energy is a clean energy source that does not run out of reserves and does not pollute the environment and is widely used in the drying of agricultural products worldwide due to its ability to be easily converted into heat energy (Gültekin, 2016).

Solar energy has the greatest potential among all renewable energy sources. Converting even a small part of this will mean that one of the best energy sources will be made available to the community. On average, solar energy that can be used on a bright sunny day can reach the levels of about $1 \mathrm{~kW} / \mathrm{m} 2$ and this energy can be used from sunrise to sunset. As solar energy technologies available and used today, heating and cooling of buildings, solar water heaters, solar air heaters, solar stoves, solar drying, etc. can be listed. Solar air heating systems are widely used in drying applications. There is a wide range of solar dryers on the market or in research. The situation has been proven in research to be useful devices in terms of energy saving. While dryers take up less space, they not only save energy but also save time. The main goal is to improve the quality of the product, to make the process more efficient than drying in open sun and to protect the environment. Solar energy can be used for the entire drying process, or it can also be used to support artificial drying systems (Güngör, 2013).

Drying, which is one of the effective techniques that can be used to maintain the quality of fruits and vegetables for a long time, has a wide application potential especially for our country. There is a significant gain from the export of fruits and vegetables grown in our country. Approximately $2 / 3$ of this fruit and vegetable potential is exported dry. The best examples of these products can be given apricot, grapes, figs, nuts, etc. For these reasons, the work related to drying of high importance should be carried out effectively and comprehensively. Our country has a high potential for dried fruits and vegetables. To increase exports at the desired rate, it is necessary to ensure the production of quality dried fruits and vegetables. To provide these quality dried fruits and vegetables, appropriate drying techniques must be selected and applied. What is desired on a manufacturer's basis is that the product dries in a shorter time and is of better quality. This creates the requirements for the use of solar systems. All these desired features (food quality, low costs, appropriate method for drying) make positive contributions to product quality. The energy required to run the fan in the solar drying system is negligible when compared to the cost-reduced mass loss, the improved quality characteristics and the additional gains achieved. Especially with the reduction in drying time, its importance increases (Çay et al., 2017).

Solar dryers are divided into two groups: natural and artificial dryers (Figure 5). Natural solar dryers do not need any energy sources other than solar energy. Sunlight is carried out by reaching the product to be dried directly and the heat is carried out by natural convection. In artificial solar dryers, drying process takes place in a closed volume consisting of drying room, solar collector and drying chimney.

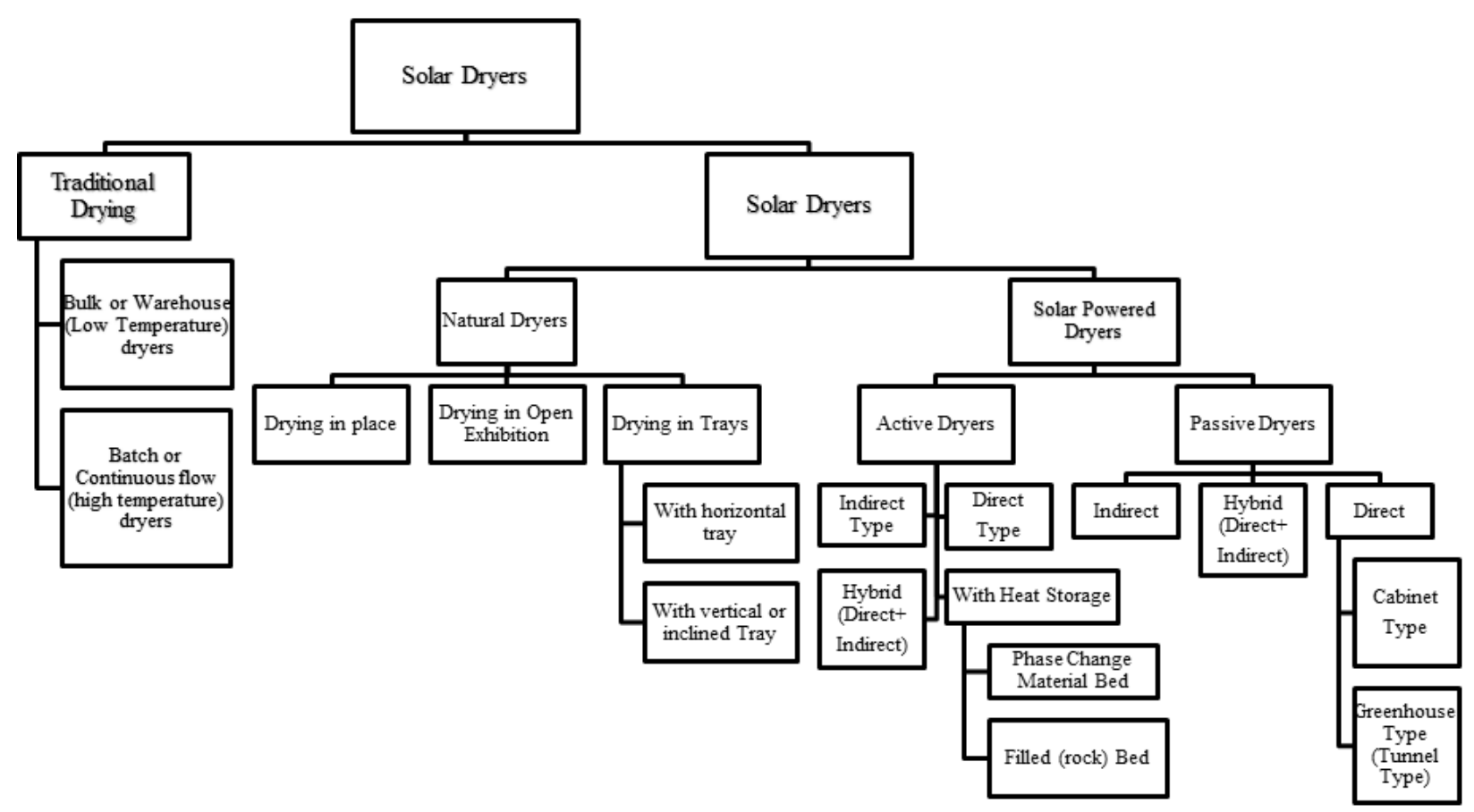

Figure 5. Solar Dryers (Güngör, 2013; Yağcıŏlu, 1999; Özbalta ve Güngör, 2012; Çay et al., 2017; Olgun, 1989; Aktaş et al., 2012; Çakır, 2015). 
The sun's rays coming into the collector heat the air taken into the dryer and this heat reaches the product to be dried by natural or forced convection, removing moisture from the product and thus providing drying. Although drying is provided in shorter periods than the natural solar dryer, the cost is high because the energy required for the operation of the fan is usually provided from conventional energy sources (Yıldız ve Gökayaz, 2020a).

The basic design features of typical solar dryers are shown in Figure 6 below.

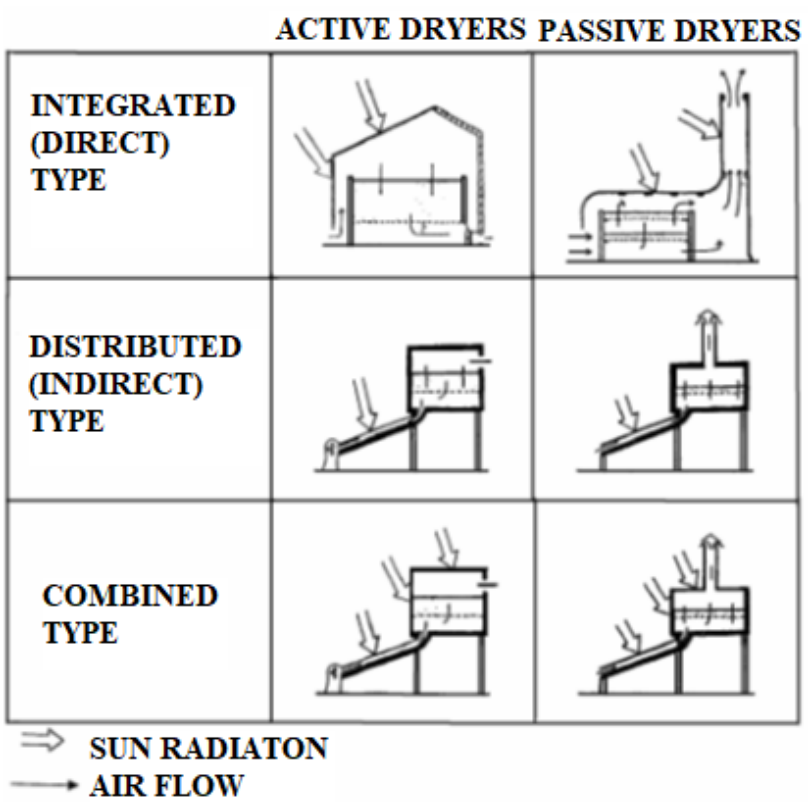

Figure 6. Basic design features of Solar Dryers (Çakır, 2015)

Çakmak (2007) designed a new solar-powered rotating flow drying system and experimentally and theoretically investigated the drying parameters in case of artificial drying of grapes grown in the Elazığ region. For experimental work, it has developed a solar drying system consisting of a new type of air solar collector, FDM collector (Phase changing material) and drying cabinet. The researcher had developed the air solar collector and reported that drying in the rotating flow dryer was uniform and that the products dried in the rotating flow environment reached lower humidity values in shorter time than the classical system. In experiments conducted at different air speeds, it was stated that drying time decreased with the increase in drying air speed.

Aktaş et al. (2012) designed and manufactured a solarpowered dryer with a capacity of $10 \mathrm{~kg}$ and dried tomatos under different conditions (drying air speed $0.2 \mathrm{~m} \mathrm{~s}^{-1}$, drying air temperatures $40-50-60^{\circ} \mathrm{C}$ ). In the dryer system they manufactured, they provided their energy needs entirely from solar energy and achieved high energy efficiency compared to existing conventional energy dryers. They have reported that this new system can be integrated into existing systems on small and large scales.

Gültekin (2016) benefited from solar energy, which is one of the sources of renewable energy. To be a cheap, high quality and sustainable system, he has designed a solar dryer using solar energy. In the study, product humidity reduced to $8 \%$ after drying and the color change values resulting from this process were given. The designed system has been reported to be suitable and efficient for drying.

Özbalta and Güngör (2012) examined solar drying systems and made efficiency definitions. In their study, they reported drying conditions for various fruits and vegetables. In addition, in their study, they defined solar drying systems and sampled dryer types.

Çakır (2015) has designed a solar greenhouse type dryer for drying spice red pepper, which is intensively produced in Şanlıurfa province. The products obtained by drying in the designed system were compared with the products dried in footed and wire fenced trays under the same conditions in terms of drying time, percentage weight loss and product quality characteristics. During daylight hours, the dryer system achieved higher drying temperature values, which led to faster weight loss. It was reported that there was no homogeneous weight loss between the racks at constant fluid speed in the system designed, and it was reported that it would be useful to combine a layout with the system that could allow the shelves to be replaced.

Çay et al. (2017) had given information about solar drying systems and reported the uses of these systems in agriculture. They stated that the widespread use of solar energy in agriculture can lead to economic, social and ecological improvements on a personal, regional and national basis. In their study, they had emphasized the need to conduct pilot applications and regional research and to expand and develop these applications.

In their study, Akman et al. (2018) had designed and manufactured a solar-powered drying system and carried out the first tests in Osmaniye climatic conditions. In the data obtained after the study, they had reported that the drying air used in the system can reach a temperature of up to $45^{\circ} \mathrm{C}$, the air temperature entering the collector can be increased by an average of $10-14{ }^{\circ} \mathrm{C}$, approximately $58 \%$ of moisture can be removed from the product during the 6 hour drying period, and the drying process has been successfully realized.

Cankurtaran (2018) had experimentally identified performance-influencing factors using a solar-powered drying system. He also had developed an energy storage system with phase change material to ensure the continuity of the drying process. He had reported that $48 \mathrm{MJ}$ of energy is stored in the developed energy storage system, which is sufficient for strawberry drying. As a result of experimental studies, he had report this drying system had a positive effect on the quality of the dried product due to its low humidity and temperature values.

In their study, Y1ldız and Gökayaz (2019) dried apples with multi-shelf solar dryer and optimized drying conditions with The Response Surface Method. In the Response Surface Method, they selected the drying parameters as the thickness of the slice, the drying time and the mass of the apple slices loaded into the tray. They chose the optimized response as drying speed, \% moisture loss and shrinkage rate. They created a model by statistically evaluating the data they obtained and determined the optimum drying values with the help of this model. They reported drying time (159-274 min.), mass of apple slices loaded on the tray (92.86-105.72 g) and apple slice 
thickness (6.48-6.667 $\mathrm{mm})$ for maximum moisture loss and shrinkage rate minimum drying speed.

Şafak (2019) had used banding solutions with different proportions in its study and used two different greenhouses, solar panel supported and without solar panel support. In the greenhouse with solar panel support, it reported that it did not dry out in the shorter time expected compared to the greenhouse without panel support, however, it was drying in about 6-7 days less than the drying time in the folded wire exhibitions. He stated that the grapes dried in the greenhouse are protected from adverse environmental conditions (dust, soil, rain) and capture the drying performance shown by the open ground exhibitions. It has also been reported that grapes dried in the greenhouse are lighter in color than open-dried grapes.

In their study, Sak et al., (2019), investigated the conditions of the solar power plant and its power generation potential in Niğde province. In this study, they stated the solar energy potential of Niğde province and the areas where solar power plants can be established. In their study, they had reported that the electricity needs of Niğde province can be met with solar power plants to be installed in $3.4 \%$ of the areas that have lost their agricultural and forest quality. The potential for drying facilities to be established in these locations should not be overlooked.

In their study, Y1ldiz and Gökayaz (2020a) had used solar dryers for apple drying. They had examined the effects of adjustable humidity on drying using a natural convective solar dryer with shelves of apples they sliced in 4 and $10 \mathrm{~mm}$ thickness. They had performed drying at different drying cabinet temperature and drying air speeds and developed mathematical modeling. By comparing the data obtained with the existing drying models in the literature, they had reported that the Henderson-Pabis model was suitable for this study.

Y1ldız and Gökayaz (2020b) had studied the optimum moisture content that needs to be removed for drying and apple slices with high drying temperature using multi-shelf solar dryer with natural convection. They had dried apple slices in three ways: multi-shelf solar dryer, directly under the sun and in the shade. Drying conditions, slice thickness, drying time, conditions of air inside the drying cabinet and shelf position were selected. They had determined the effect of these drying conditions on apple drying with moisture loss, drying speed and shrinkage rates. They had reported that drying apple slices with multi-shelf solar dryer is faster than drying directly into the sun and in shade. They had stated that drying increased due to increased air temperature in the dryer, decreased apple slice thickness and increased drying time.

Timurtaş (2020), had dried peach slices of different thicknesses with a solar energy-powered system with thermal energy storage system. He had applied drying between 6-8 hours depending on the different temperature values in the drying cabinet. The researcher had report that the average power gained by working together with the solar-powered thermal storage system and recovery system was $8.63 \mathrm{kWh}$ and the energy needs of the drying system were $15.5 \mathrm{kWh}$. According to this data, he had achieved approximately $45 \%$ savings in electrical energy in the product drying process with the system it has developed.
Baltacıoğlu et al (2015), used microwave, hot air and sun drying methods for drying quince slices. In their study, they reported that the effect of sun drying method on quality parameters was the same as the microwave method and showed better properties than hot air drying. In the same study, when drying times were examined, they stated that drying in the sun was disadvantageous.

\section{Results and Discussion}

When the solar energy usage potentials of the world are evaluated, it is seen that Turkey has very high averages compared to many countries. Niğde Province is one of the regions that played a role in the rise of the solar energy average. Due to the intensity of apple production, which is the most important pillar of the existing agricultural activities in Niğde, it is inevitable that different commercial activities in the apple sector will have direct and indirect effects. In this context, it is possible to say that apple drying processes, which have increased in popularity in recent years, will have great contributions to both the producer and the economy of country. The methods and technologies to be selected for the drying of food products should be evaluated and determined after feasibility studies are carried out at the location of the facility. The use of solar energy in the drying process means to take advantage of an important available and ready-to-use energy source and significantly shortens the time between energy supply and demand. One of the most important potential applications of solar energy is its use in drying agricultural products.

Although the most common drying method in our country is open drying, the disadvantages of this method are evaluated; the usage of these methods and technologies mentioned in the study will have positive effects on both economic inputs and yield values. In this context, it is possible to say that it is wise to use solar-powered drying systems in different evaluation of the products obtained because of agricultural production activities, such as drying. Products produced because of agricultural production activities are one of the main sources of nutrition for humans and animals. Making the most of the resulting products reduces the loss of productivity for both producers and consumers. Without deterioration, it is necessary to process products of quality, where consumption can occur, and which need to be stored for a long time, by various methods. Drying from these processes is widely used in the world and in our country. Although the solar energy potential of our country varies according to the geographical locations of the provinces, Niğde province is among the provinces with high potential because of the current data. Solar energy is renewable, inexpensive, it is wise to use because its source is infinite energy. Although the high initial investment costs reduce the interest in this type of energy, the incentives will increase investments. Using solar dryers for drying agricultural products will increase the efficiency of the products in terms of time and cost compared to drying them by traditional methods, as well as reduce quality losses and increase their added value. Current studies support manufacturers' preference for this method. 
Producing products with low losses, cheap and high quality will lead to the increase of dried fruit exports, which have an important place in the revenues of our country. Using solar dryers for drying will allow for increased environmentally friendly production and continued sustainability in agriculture. With the incentives to be given by the state, it should be ensured that investment in this field is increased, and producers and investors pay attention to this area. Studies on solar dryers and solar systems should be supported and the publication of the results should be encouraged. In addition, the level of awareness should be increased with trainings and information to be given to producers and investors at regular intervals.

\section{Acknowledgment}

This article was presented as an oral presentation in II. International Turkish Journal of Agriculture - Food Science and Technology Congress (TURJAF 2021).

\section{Authors' Contributions}

Yaşar Serhat Saygllı: Validation, Writing - original draft, Review and editing, Methodology, Investigation, Conceptualization, Visualization.

Ali Kaan Yetik: Methodology, Investigation, Conceptualization, Validation, Review and editing.

Furkan Baş: Investigation, Validation, Writing original draft, Visualization.

Burak Şen: Formal analysis, Data curation, Review and editing.

\section{Conflict of Interest}

The authors declare that they have no conflict of interest.

\section{References}

Aboul-Enein S, El-Sebaii A, Ramadan M, El-Gohary H. 2000. Parametric Study of a Solar Air Heater with and without Thermal Storage for Solar Drying Applications. Renewable Energy, 21 (3-4), 505-522.

Akman H, Çerçi KN, Hürdoğan E, Büyükalaca O. 2018. Güneş Enerjisi Destekli Bir Kurutma Sisteminin Tasarımı, İmalatı ve İlk Ölçüm Sonuçlarının Değerlendirilmesi. Osmaniye Korkut Ata Üniversitesi Fen Bilimleri Enstitüsü Dergisi, 1(1), $1-9$.

Aktaş M, Şevik S, Doğan H, Öztürk M. 2012. Fotovoltaik ve Termal Güneş Enerjili Sürekli Bir Kurutucuda Domates Kurutulması. Tarım Bilimleri Dergisi, 18, 287-298.

Ayensu A. 1997. Dehydration of Food Crops Using a Solar Dryer with Convective Heat Flow. Solar Energy, 59 (4-6), 121-126.

Baltacioğlu C, Uslu N, Özcan MM. 2015. Optimization of Microwave and Air Drying Conditions of Quince (Cydonia Oblonga, Miller) Using Response Surface Methodology. Italian Journal of Food Science, 27(1), 50-56.

Banga JR, Perez-Martin RI, Gallardo JM, Casares J. 1991. Optimization of the Thermal Processing of ConductionHeated Canned Foods: Study of Several Objective Functions. Journal of Food Engineering, 14 (1), 25-51.

Can A. 2000. Drying Kinetics of Pumpkinseeds. International Journal of Energy Research, 24 (11), 965-975.
Cankurtaran E. 2018. Güneş Enerjili Kurutma Sisteminde Çileğin Kurutma Karakteristiğinin Belirlenmesi. MSc Thesis. Institute of Natural and Applied Sciences, Yozgat Bozok University, Yozgat, Turkey.

Ceylan İ, Aktaş M, Doğan H. 2006. Güneş Enerjili Kurutma Fırınında Elma Kurutulması. Politeknik Dergisi, 9(4), 289294. doi: 10.2339/2006.9.4.289-294

Chiang WC, Petersen JN. 1987. Experimental Measurement of Temperature and Moisture Profiles During Apple Drying. Drying Technology, 5 (1), 25-49.

Close D. 1963. Solar Air Heaters for Low and Moderate Temperature Applications. Solar Energy, 7 (3), 117-124.

Çakır MT. 2015. Güneş Enerjisinden Yararlanarak Tarım Ürünlerinin Kurutulması. Gazi Mühendislik Bilimleri Dergisi (GMBD), 1(1), 41-55.

Çakmak G. 2007. Çekirdekli Üzüm Kurutmada Güneş Enerjisi Destekli Dönel Akışlı Kurutucu Tasarımı. PhD Dissertation. Institute of Natural and Applied Sciences, Firat University, Elâzı ̆̆, Turkey.

Çay VV, Koçyiğit F, Akyüz MK, Koçyiğit Ş. Güneş Enerjili Kurutma Sistemleri ve Tarımda Kullanımı. International Engineering Conference. Diyarbakır, Turkey, Ekim 2017, pp. 302-314.

EİGM, 2021. Enerji İşleri Genel Müdürlüğü. Türkiye Güneş Enerjisi Potansiyel Atlas1 (GEPA). Available from: https://gepa.enerji.gov.tr/MyCalculator/pages/51.aspx [Accessed 04.10.2021[

FAO, 2021. Food and Agriculture Organization of the United Nations. Food And Agriculture Data. Available from: http://www.fao.org/faostat/en/ [Accessed 10.03.2021]

Fatih HE. 1995. Thermal Performance of a Simple Design Solar Air Heater with Built-In Thermal Energy Storage System. Renewable Energy, 6 (8), 1033-1039.

Gültekin R. 2016. Şanlıurfa Şartlarında Patlıcanın Kurutulmasında Güneş Enerjili Kurutma Makinesi Geliştirilmesi. MSc Thesis. Institute of Natural and Applied Sciences, Harran University, Şanlıurfa, Turkey.

Güneş NÇ. 2009. Gıda Kurutma Sistemlerinin Ekserji Analizi. $\mathrm{PhD}$ Dissertation. Institute of Natural and Applied Sciences, Ege University, İzmir, Turkey.

Güngör A. Sebze ve Meyve Kurutmada Kullanılan Kurutucular ve Kurutma Teknolojileri. 11. Ulusal Tesisat Mühendisliği Kongresi, Nisan 2013, pp. 43-63.

Gürel AE, Ceylan İ, Aktaş M. 2016. Meyve ve Sebzelerin Kurutma Parametrelerinin Incelenmesi. Gazi Üniversitesi Fen Bilimleri Dergisi Part C: Tasarım Ve Teknoloji, 4(4), 267-273.

Kaya A, Aydın O, Demirtaş C. 2007. Drying Kinetics of Red Delicious Apple. Biosystems Engineering, 96 (4), 517-524.

Kibar H, Öztürk T. Depolamada Ortaya Çıkan Ürün Kayıplarının Nedenleri ve Çözüm Önerileri. I. Ulusal Sulama ve Tarımsal Yapılar Sempozyumu. Kahramanmaraş Sütçü İmam Üniversitesi, Kahramanmaraş, Turkey, Mayıs 2010, pp. 806815.

Lewicki PP, Jakubczyk E. 2004. Effect Of Hot Air Temperature on Mechanical Properties of Dried Apples. Journal Of Food Engineering, 64 (3), 307-314.

Mayor L, Silva M, Sereno A. 2005. Microstructural Changes During Drying of Apple Slices. Drying Technology, 23(911), 2261-2276.

NOHÜ, 2021a. Niğde Ömer Halisdemir Üniversitesi. Döner Sermaye İşletme Müdürlüğü. Available from: https://www.ohu.edu.tr/donersermaye/duyuru/13254 [Accessed 10.03.2021]

NOHÜ, 2021b. Niğde Ömer Halisdemir Üniversitesi . Döner Sermaye İşletme Müdürlüğü. Available from: https://www.ohu.edu.tr/donersermaye/duyuru/26065 [Accessed 10.03.2021] 
Olgun N. 1989. Güneş Enerjisi ile Sebze ve Meyve Kurutma Teknikleri. MsC Thesis. Institute of Natural and Applied Sciences, Gazi University, Ankara, Turkey.

Oral Z. 2015. Dünya'da ve Türkiye'de Gıda İsrafi ve Önlenmesine Yönelik Uygulamalar, AB Uzmanlık Tezi, T.C. Gıda Tarım ve Hayvancılık Bakanlığı Avrupa Birliği ve Dış İlişkiler Müdürlüğü, Ankara.

Özbalta N, Güngör A. 2012. MMO. Güneş Enerjili Kurutma Teknolojileri ve Uygulamalarda Gelişmeler. Available from: https://www.mmo.org.tr/sites/default/files/10\%20-

\%20G\%C3\%9CNE\%C5\%9E\%20ENERJ\%C4\%B0L\%C4\% B0\%20KURUTMA\%20TEKNOLOJ\%C4\%B0LER\%C4\%B $0 \% 20 \mathrm{ve} \% 20$ UYGULAMALARDA\%20GEL\%C4\%B0\%C5 $\% 9$ EMELER $\% 20$

\%20Prof.\%20Dr.\%20Ali\%20G\%C3\%BCng\%C3\%B6r.pdf [Accessed 11.03.2021]

Pangavhane DR, Sawhney R, Sarsavadia P. 2002. Design, Development and Performance Testing of a New Natural Convection Solar Dryer. Energy, 27 (6), 579-590.

Saçılık K, Eliçin AK. 2006. The Thin Layer Drying Characteristics of Organic Apple Slices. Journal Of Food Engineering, 73 (3), 281-289.

Sak T, Gönen Ç, Kara EE. 2019. Niğde İlinde Güneş Enerjisi Santrallerinin Yaygınlaştırılması ve Sera Gazı Emisyonlarının Azaltılmasının Potansiyeli. Fırat Üniversitesi Müh. Bil. Dergisi, 31(2), 327-335.

Sharma VK, Colangelo A, Spagna G. 1995. Experimental Investigation of Different Solar Dryers Suitable for Fruit and Vegetable Drying. Renewable Energy, 6 (4), 413-424.

Srikiatden J, Roberts JS. 2007. Moisture Transfer in Solid Food Materials: A Review of Mechanisms, Models, and Measurements. International Journal of Food Properties, 10(4), 739-777.

Şafak M. 2019. Güneş Enerjili Kurutma Sistemlerinin Çekirdeksiz Kuru Üzüm Üretimine Etkileri. MSc Thesis. Institute of Natural and Applied Sciences, Ege University, İzmir, Turkey.

TCETKB, 2021. T.C. Enerji ve Tabii Kaynaklar Bakanlığı. Türkiye Güneş Enerjisi Potansiyeli Atlası. Available from: https://enerji.gov.tr/Preview/tr/974188aa-fa6b-4349-89dd$300 \mathrm{~b} 2 \mathrm{f} 7 \mathrm{efb} 24$ [Accessed 04.10.2021]
Timurtaş Ö. 2020. Enerji Depolama Sistemli Güneş Enerjili Gıda Kurutma Sistemlerinde Kurutma Performansinın İncelenmesi. PhD Dissertation. Institute of Natural and Applied Sciences, Ege Üniversitesi, İzmir, Turkey.

TÜİK, 2021. Türkiye İstatistik Kurumu. Available from: https://tuikweb.tuik.gov.tr/pretablo.do?alt_id=1001 [Accessed 10.03.2021]

Üretir G, Özilgen M, Katnaş S. 1996. Effects of Velocity and Temperature of Air on the Drying Rate Constants of Apple Cubes. Journal Of Food Engineering, 30 (3-4), 339-350.

Velić D, Planinić M, Tomas S, Bilić M. 2004. Influence of Airflow Velocity on Kinetics of Convection Apple Drying. Journal Of Food Engineering, 64(1), 97-102.

Whillier A. 1964. Performance of Black-Painted Solar Air Heaters of Conventional Design. Solar Energy, 8 (1), 31-37.

Yadav Y, Kumar A, Sharan L, Srivastava V. 1995. Parametric Analysis of a Suspended Flat Plate Solar Air Heater. Energy Conversion and Management, 36 (5), 325-335.

Yadav Y, Tiwari G. 1986. Transient and Analytical Solution of Suspended Flat-Plate Solar Air Heater. Energy Conversion and Management, 26 (3-4), 265-269.

Yağcıŏglu A.K. 1999. Tarım Ürünleri Kurutma Tekniği. Ege Üniversitesi Ziraat Fakültesi Yayınları, 536. İzmir.

Yaldız O, Ertekin C, Uzun H. I. 2001. Mathematical Modeling of Thin Layer Solar Drying of Sultana Grapes. Energy, 26 (5), 457-465.

Yıldız Z, Gökayaz L. 2019. Güneş Enerjili Kurutucuda Kurutulan Elma Dilimlerinin Kurutma Koşullarının RSM ile Optimizasyonu. Çukurova Tarım ve Gıda Bilimleri Dergisi, 34(2), 100-108. doi:10.36846/CJAFS.2019.2

Yıldız Z, Gökayaz L. 2020a. Çok Raflı Güneş Enerjili Kurutucu İle Elma Kurutma İşlemi Üzerine Kurutma Koşulların Etkisi. Gaziosmanpaşa Bilimsel Araştırma Dergisi, 9(1), 27-36.

Yıldız, Z, Gökayaz L. 2020b. Raflı Doğal Konvektif Güneş Enerjili Kurutucuda Elma Kuruma Kinetiğinin İncelenmesi. Engineering Sciences, 15(1), 34-42. 